\title{
Deoxyribonucleic Acid Homology of Aerococcus viridans ${ }^{1}$
}

\author{
L. M. SCHULTES ${ }^{2}$ AND JAMES B. EVANS \\ Department of Microbiology, North Carolina State University, \\ Raleigh, North Carolina 27607
}

\begin{abstract}
Deoxyribonucleic acid (DNA) was purified from cultures of 16 strains that, on the basis of physiological tests, appeared to be strains of Aerococcus viridans (although one was named Gaffkya homari and two were called Aerococcus catalasicus). The DNA base composition of 15 of these strains, as determined by the thermal denaturation technique, was within the range of 37.0 to $40.2 \%$ guanine plus cytosine. The relative nucleotide sequence homology was measured by DNA-DNA hybridization on nitrocellulose membrane filters. The DNA from most strains hybridized with the DNA from other strains to the extent of 69 to $100 \%$ of the level of homologous binding. Limited studies indicated that under the conditions of these studies there was less than $12 \%$ homology with the DNA of several pediococci, one enterococcus, and one strain of Gaffkya tetragena.
\end{abstract}

The bacterial species Aerococcus viridans (9) appears to be widely dispersed in our environment and to be quite homogeneous with respect to physiological characteristics, nutritional requirements, and deoxyribonucleic acid (DNA) base composition $(4,5,8)$. However, there remain questions regarding its taxonomic relationship to other genera of gram-positive cocci, particularly those with a tendency toward tetrad formation and with a DNA base composition between 30 and $45 \%$ guanine plus cytosine (GC). The present study was an attempt to learn more about the nucleotide homology of these organisms by measuring the relative amount of DNA-DNA hybrid formation under standardized conditions.

\section{MATERIALS AND METHODS}

Cultures and growth conditions. The bacterial strains studied and their sources are listed in Table 1. Cells for DNA extraction were grown at $30 \mathrm{C}$ in Trypticase Soy Broth (BBL). Cells were harvested in the early stationary phase. If the test culture was a pediococcus or a streptococcus, 1,000 units of penicillin G (Eli Lilly \& Co., Indianapolis, Ind.) was added

1 Paper no. 2952 of the Journal Series of the North Carolina State University Agricultural Experiment Station, Raleigh. This work is taken from a dissertation submitted by the senior author (L.M.S.) in partial fulfillment of the requirements for the Ph.D. Degree.

2 Present address: St. Luke's Pathology Associates, St. Luke's Hospital, Milwaukee, Wis. 53215. to the flask 4 to $6 \mathrm{hr}$ before harvesting the cells. This treatment rendered the cells sensitive to lysozyme.

Production of labeled DNA. Most cultures were labeled by the addition of $15 \mu \mathrm{Ci}$ of adenine- $-8{ }^{14} \mathrm{C}$ (Calbiochem, Los Angeles, Calif.) per liter of growth medium. However, some cultures did not incorporate adenine; for these, $20 \mu \mathrm{Ci}$ of [methyl ${ }^{3} \mathrm{H}$ ] thymidine (New England Nuclear, Boston, Mass.) was added per liter of medium.

DNA isolation. The harvested cells were lysed, and the DNA was extracted and purified by the method of Marmur (6) as modified by Auletta and Kennedy (1) The amount of DNA was measured as absorbance at $260 \mathrm{~nm}$.

Determination of DNA base composition. Thermal denaturation curves were determined, and the DNA base composition as moles per cent guanine plus cytosine (\% GC) was calculated by the method of Marmur and Doty (7).

DNA-DNA hybridization. Unlabeled DNA was denatured by heating at $100 \mathrm{C}$ for $5 \mathrm{~min}$ in SSC $(0.15$ $\mathrm{M} \mathrm{NaC1}$ and $0.015 \mathrm{M}$ sodium citrate, $p \mathrm{H}$ 7.0). Twenty-microgram amounts of this DNA in $6 \times$ SSC were fixed on $25-\mathrm{mm}$ nitrocellulose membrane filters (B-6, Schleicher and Schuell Co., Keene, N. H.) by the method of Denhardt (3). Filter quarters with DNA affixed were placed in scintillation vials with $1.0 \mathrm{ml}$ of Denhardt's preincubation mix (all ingredients from Sigma Chemical Co., St. Louis, Mo.) at 67 to $69 \mathrm{C}$ for 5 to $6 \mathrm{hr}$. Labeled DNA in SSC was sheared by passing 10 times through a $1-\mathrm{ml}$ tuberculin syringe with a 5/8-inch 25-gauge needle, denatured, cooled, and brought to $2 \times$ SSC. A $0.5-\mathrm{ml}$ amount ( 1 to $5 \mu \mathrm{g}$ ) was added to a filter quarter that had been removed from the preincubation mix, blotted dry, and incubated at 
67 to $69 \mathrm{C}$ for $12 \mathrm{hr}$. Under these conditions, it was found that over $90 \%$ of the unlabeled DNA was fixed to the filter pad and that approximately $30 \%$ of the labeled homologous DNA was bound to unlabeled DNA, whereas less than $2 \%$ of the labeled DNA was bound to filters with unlabeled DNA from organisms belonging to genera other than Aerococcus. The amount of labeled DNA bound to unlabeled DNA from the same bacterial strain (a homologous cross) was considered $100 \%$ homology for that particular experiment. The relative amount bound to unlabeled DNA from other bacterial strains (heterologous crosses) was considered to be a relative measure of the homology with these strains.

\section{RESULTS}

DNA base composition. Each batch of DNA that was purified for these studies was subjected to thermal denaturation, and the DNA base composition was calculated from the absorbancy-temperature profile. The results are summarized in Table 1. All strains that had been classified as Aerococcus had 37.0 to 40.2\% GC except for strain MK-165 which had only $35.8 \%$ GC. Two cultures (Aerococcus $\mathrm{C}_{2}$ and $G$. tetragena 10875 ) gave results that differed from values previously reported from this laboratory (5). The two Gaffkya cultures were not distinguishable from the Aerococcus cultures, although the $G$. tetragena had a GC content slightly below the aerococci in the present study. The Pediococcus strains gave evidence of species differences, with $P$. pentosaceus having a GC content slightly below that of the aerococci and the two strains of $P$. acidilactici having a GC content slightly above that of the aerococci.

DNA-DNA hybridization. In Table 2 are presented data for four strains of aerococci for which complete reciprocal crosses have been repeated at least twice. The values for the six reciprocal crosses ranged from agreement within $1 \%$ (301 versus 303 ) to $15 \%\left(\mathrm{C}_{6}\right.$ versus 302$)$. For eight other pairs that have been crossed reciprocally at least twice, there also is agreement within 2 to $15 \%$. Furthermore, in all of the 14 reciprocal crosses, the average per cent homology fell within the range of 69 to $100 \%$.

Table 3 summarizes in a qualitative manner the results of our hybridization experiments. All of the Aerococcus cultures tested, except MK-165, generally gave homology values of 69 to $100 \%$ when crossed with other aerococci. In 13 crosses between MK-165 and other aero-

TABLE 2. DNA homology of reciprocal hybridizations

\begin{tabular}{c|rrrr}
\hline \multirow{2}{*}{$\begin{array}{c}\text { Unlabeled, fixed } \\
\text { phase (strain) }\end{array}$} & \multicolumn{4}{|c}{$\begin{array}{c}\text { Labeled, mobile phase } \\
\text { (\% homology) }\end{array}$} \\
\cline { 2 - 5 } & $\mathrm{C}_{6}$ & 301 & 302 & 303 \\
\hline $\mathrm{C}_{6}$ & 100 & 97 & 90 & 92 \\
301 & 95 & 100 & 86 & 76 \\
302 & 75 & 89 & 100 & 70 \\
303 & 86 & 75 & 82 & 100 \\
\hline
\end{tabular}

TABLE 1. Source and DNA base composition of bacterial strains used in this study

\begin{tabular}{|c|c|c|c|}
\hline Bacterial strain & $\% \mathrm{GC}$ & Bacterial strain & $\% \mathrm{GC}$ \\
\hline Gaffkya tetragena $10875^{a}$ & 33.0 & A. viridans $\mathrm{MK}-95^{b}$ & 38.5 \\
\hline Pediococcus pentosaceus $\mathrm{P} 1 c$ & 35.6 & A. viridans $11563^{a, d}$ & 38.5 \\
\hline Aerococcus viridans $\mathrm{MK}-165^{b}$ & 35.8 & A. viridans $\mathrm{MK}-3^{b}$ & 38.7 \\
\hline A. viridans $\mathrm{MK}-132^{b}$ & 37.0 & A. viridans $301^{e}$ & 38.8 \\
\hline A. viridans $\mathrm{MK}-146^{b}$ & 37.1 & A. catalasicus $\mathrm{C}_{9} f$ & 38.9 \\
\hline A. viridans $\mathrm{C}_{2} f$ & 37.1 & A. catalasicus $\mathrm{C}_{6} f$ & 39.4 \\
\hline Streptococcus faecalis R-53b & 37.5 & A. viridans $303^{e}$ & 39.9 \\
\hline A. viridans $302^{e}$ & 37.6 & A. viridans $\mathrm{C}_{7} f$ & 40.2 \\
\hline A. viridans $\mathrm{MK}-53^{b}$ & 37.6 & Pediococcus acidilactici SP- ${ }^{c}$ & 42.2 \\
\hline A. viridans $\mathrm{MK}-201^{b}$ & 37.6 & P. acidilactici $\mathrm{SP}-4 c$ & 43.3 \\
\hline Gaffkya homari $10400^{a}$ & 37.9 & & \\
\hline
\end{tabular}

\footnotetext{
$a$ Culture obtained from American Type Culture Collection, Rockville, Md.

$b$ Culture maintained in culture collection, Department of Microbiology, North Carolina State University, Raleigh, N.C.

$c$ Culture obtained from R. Whittenbury, School of Agriculture, Edinburgh, Scotland.

$d$ Type strain.

$e$ Culture obtained from A. C. Baird-Parker, Unilever Research Laboratory, Sharnbrook, Bedford, U.K.

$f$ Culture obtained from O. G. Clausen, University of Oslo, Blindern, Norway.
} 
TABLE 3. Summary of DNA-DNA hybridization data

\begin{tabular}{llcccc}
\hline \multicolumn{1}{c}{ Cultures } & Aerococci & MK-165 & $\begin{array}{c}\text { Gaffkya } \\
\text { homari }\end{array}$ & $\begin{array}{c}\text { Gaffkya } \\
\text { tetragena }\end{array}$ & Pediococci \\
\hline $\begin{array}{l}\text { Aerococci }(15)^{a} \\
\quad(\text { except MK-165) }\end{array}$ & $69-100^{b}$ & & & & \\
Strain MK-165 & $30-56$ & & & & \\
Gaffkya homari & $40-95$ & $41-55$ & & & \\
Gaffkya tetragena & $2-9$ & 3 & $6-9$ & & \\
Pediococci (3) & $3-12$ & 1 & 1 & $2-3$ & $2-3$ \\
Streptococcus faecalis & $2-6$ & $2-5$ & 3 & & \\
\hline
\end{tabular}

$a$ Number of strains tested.

$b$ Range of values, including reciprocal crosses. All figures shown represent percentages.

cocci, the homology values range from 30 to $56 \%$. The culture of $G$. homari in 24 crosses with aerococci gave values of 40 to $95 \%$, with an average of $74 \%$ homology. However, the $G$. tetragena showed only 2 to $9 \%$ homology with aerococci and only 6 to $9 \%$ with the $G$. homari strain. One culture of Streptococcus faecalis in 14 crosses with aerococci indicated only 2 to $6 \%$ homology, and three cultures of Pediococcus in 10 crosses with aerococci gave 3 to $12 \%$ homology.

\section{DISCUSSION}

Both the DNA base composition data and the hybridization studies support the concept of $A$. viridans as a biologically valid species. The one strain of $G$. homari that was included in this study appeared to belong in the same species as $A$. viridans, as suggested on the basis of physiological studies (2). Like many strains that have been maintained in culture collections over a period of years, this organism grows more slowly and is less active in a variety of physiological tests when compared to organisms that have been isolated more recently.

Strain MK-165 has a DNA base composition slightly below that of typical $A$. viridans and its DNA hybridizes somewhat less readily. Nutritional studies (8) also suggest minor differences between this strain and typical $A$. viridans. For the present it seems advisable to withhold judgment as to whether this culture may belong to a second species of Aerococcus or is simply an odd strain of $A$. viridans.

There is no evidence of close DNA homology between the aerococci and the strains of pediococci, the enterococcus, or the G. tetragena that were included in this study.

\section{ACKNOWLEDGMENTS}

This investigation was supported by Public Health Service grant AI-07693 from the National Institute of
Allergy and Infectious Diseases and Public Health Service training grant GM-01265 from the National Institute of General Medical Sciences. During the early portion of this study, the senior author was supported by a National Defense Education Act Title IV Graduate Fellowship.

We thank Mildred A. Kerbaugh, A. C. BairdParker, O. G. Clausen, and R. Whittenbury for providing the cultures used in this study.

\section{LITERATURE CITED}

1. Auletta, A. E., and E. R. Kennedy. 1966. Deoxyribonucleic acid base composition of some members of the Micrococcaceae. J. Bacteriol. 92:28-34.

2. Deibel, R. H., and C. F. Niven, Jr. 1960. Comparative study of Gaffkya homari, Aerococcus viridans, tetrad-forming cocci from meat curing brines, and the genus Pediococcus. J. Bacteriol. 79:175-180.

3. Denhardt, D. 1966. A membrane-filter technique for the detection of complementary DNA. Biochem. Biophys. Res. Commun. 23:641-646.

4. Evans, J. B., and M. A. Kerbaugh. 1970. Recognition of Aerococcus viridans by the clinical microbiologist. Health Lab. Sci. 7:76-77.

5. Evans, J. B., and L. M. Schultes. 1969. DNA base composition and physiological characteristics of the genus Aerococcus. Int. J. Syst. Bacteriol. 19:159-163.

6. Marmur, J. 1961. A procedure for the isolation of deoxyribonucleic acid from micro-organisms. J. Mol. Biol. 3:208-218.

7. Marmur, J., and P. Doty. 1962. Determination of the base composition of deoxyribonucleic acid from its thermal denaturation temperature. J. Mol. Biol. 4:109-118.

8. Miller, T. L., and J. B. Evans. 1970. Nutritional requirements for growth of Aerococcus viridans. J. Gen. Microbiol. 61:131-135.

9. Williams, R. E. O., A. Hirch, and S. T. Cowan. 1953. Aerococcus, a new bacterial genus. J. Gen. Microbiol. 8:475-480. 